\title{
В. В. Ніколаєв
}

orcid.org/0000-0002-5896-8191 аспірант

Національного медичного університету імені О. О. Богомольця

\section{ФОРМУВАННЯ ПРОФЕСІЙНИХ МОВНО-КОМУНІКАТИВНИХ КОМПЕТЕНТНОСТЕЙ МАЙБУТНІХ ЛІКАРІВ В УМОВАХ ДИСТАНЦІЙНОÏ ОСВІТИ}

Стаття присвячена дослідженню питань фрормування мовно-комунікативних компетентностей у рамках он-лайн взаємодії. Актуальність роботи зумовлена викликами сучасності, які ставлять перед навчальними закладами та студентами вимогу щодо опанування й застосування інформаційно-комунікаційних технологій для підвищення рівня професійної компетентності, зокрема медичного працівника.

Метою дослідження є теоретичний аналіз напрямів оптимізації навчального контенту й дистанційної взаємодії з організаційної точки зору в рамках підвищення комунікаційних навичок майбутніх фахівців. За основні методи взято індукцію, моделювання, синтез, аналіз, екстраполювання.

У роботі доведено позитивний вплив та окреслено суттєві переваги дистанційної освіти як одного з форматів розвитку мовно-комунікативних компетентностей майбутніх лікарів. Досліджено концепт «професійна компетентність», закцентовано увагу на їі інтегративній природі. Виокремлено роль домінуючої педагогічної технології в рамках відповідного навчального курсу. Указано на інтенсифрікацію ролі самовиховання належних профресійних комунікативних навичок як специфрічної властивості дистанційної освіти. Розкрито складові елементи комунікативної компетентності майбутнього лікаря.

Продемонстровано організаційні можливості, які дає дистанційна освіта на сучасному етапі розвитку науки й техніки, а також запропоновано окремі способи адаптації контенту й комунікативної взаємодії. Наголошено на необхідності проведення інтерактивних ігор, розвитку профресійної мовно-комунікативної компетентності за допомогою ситуативних кейсів, що має розвинути в студентів-медиків діалогічне та монологічне мовлення. У зазначених умовах важливо коректно організувати он-лайн формат взаємодії й оптимізувати навчальний матеріал і його контент відповідно до тих можливостей, які надають інформаційно-комунікаційні платформи. Цілком виправдано з боку викладача акцентувати увагу саме на комунікативній тематиці та розвивати в студентів діалогічне й монологічне мовлення, оперуючи професійною лексикою. Подальші наукові пошуки на базі окресленої тематики автори вбачають в експериментальних перевірках ефрективності впливу дистанційного навчання на розвиток комунікативних навичок.

Ключові слова: дистанційна освіта, комунікативні компетентності, майбутній лікар, «професійна компетентності».

Постановка проблеми. Дослідження питання розвитку мовно-комунікативних компетентностей неодноразово ставало предметом наукових пошуків сучасних учених і темою для дискусій у відповідному професійному колі. Уміння коректно оперувати професійною лексикою, розуміти її змістовне наповнення, у подальшому знаходити спільну мову із колегами та пацієнтами різного віку, статі, інтелектуальних і психолого-соціальних особливостей суттєво вливає як на авторитет цієї сфери, так і на якість медичного обслуговування загалом. У зазначеному контексті значно інтенсифікується роль і значення української мови за професійним спрямуванням як навчальної дисципліни.

Аналіз останніх досліджень і публікацій. Ураховуючи зміни в навчальному процесі, спричинені пандемією коронавірусної хвороби (SARS-
CoV-2), вітчизняні та зарубіжні вищі навчальні заклади й коледжі на певний час перейшли до формату дистанційної освіти, що суттєво ускладнює процес опанування фахових дисциплін. Окрім того, медична лексика не позиціонується як рамкова, оскільки акумулює в собі сукупність професійних термінів біологічного, психологічного, фрізіологічного спрямування. Саме тому актуальним $є$ питання адаптації студентів і викладачів до нового режиму взаємодії та оптимізації навчального матеріалу, зокрема того, що стосується формування професійних мовно-комунікативних компетентностей майбутніх лікарів.

Мета статті. Метою дослідження є оптимізація навчального контенту та способів взаємодії в рамках дистанційного навчання майбутніх лікарів, зокрема, щодо формування мовно-комунікативних навичок. 
Методи дослідження включають комплекс загальнотеоретичних (індукція, моделювання, синтез, аналіз та структурний методи) і спеціальних (теорія комунікації, моделювання комунікативних актів, екстраполювання закономірностей психолінгвістики) методів.

Виклад основного матеріалу. Ретроспектива концепту «професійна компетентність» указує на її тісний етимологічний зв'язок із такими поняттями, як професіоналізм, майстерність, належний рівень підготовки до реалізації трудового потенціалу в певній сфері. Значна кількість вітчизняних науковців схильна зіставляти компетентність із суб'єктивними характеристиками особи, ії когнітивно-інтелектуальними й організаторськими вміннями, які за певних умов можуть бути застосовані [1; 2; 6]. У свою чергу, результати досліджень у сфері психолінгвістики, лінгводидактики, педагогіки трактують зазначене поняття амбівалентно: а) через призму бекграунду як наслідок системної взаємодії фахівців однієї професійної сфрери; б) убачаючи в ньому індивідуальні властивості кожної особи.

На нашу думку, доречно звернути увагу на позицію Н. Кузьміної, яка наголошує на інтегративній природі компетентності, тим самим підкреслюючи її ускладнену архітектуру. Так, на перший погляд два незалежні компоненти «діяльність» і «комунікація» знаходять точки перетину в причиново-наслідковому зв'язку: структурований набір знань і навичок, уміння їх застосовувати на практиці та вирішувати проблемні питання шляхом вербальної й невербальної комунікації з іншими зацікавленими сторонами формують у майбутніх спеціалістів професійну компетентність [4]. Безумовно, зазначений процес неможливо успішно реалізувати без самовиховання та самовдосконалення.

Транслюючи поняття «професійна компетентність» через медичну сореру наукового пізнання, І. Крицький, П. Гощинський, Т. Крицький, І. Горішній, О. Мочульська, Г. Крицька «професійну компетентність майбутнього лікаря» досить влучно розкривають шляхом переліку завдань, що стоять на шляху до їх формування, як «теоретичну і практичну підготовленість студента на основі особистих і професійно важливих якостей; стан сформованості професійних знань, умінь і навичок, ціннісних орієнтацій, культури мовлення, стилю спілкування, аналітичних, прогностичних, проектувальних здібностей, необхідних для виконання діяльності лікаря», а формування цієї компетентності в закладі вищої медичної освіти розглядають «як процес оволодіння стійкими, інтегрованими, системними знаннями з природничо-гуманітарних, фундаментальних і клінічних дисциплін; уміння застосовувати їх у нових, нестандартних ситуаціях; розвиток особистісно важливих якостей і професійно важливих власти- востей, що забезпечить особистісне становлення майбутнього лікаря» [3, с. 46].

Комунікативна компетентність майбутнього лікаря, як і будь-який феномен, має свої складові елементи. По-перше, мотиваційний особистісний і професійний складники, що розкривається в потребі систематичної взаємодії з оточенням (колегами), тяжінні до позитивних контактів. По-друге, ідеться про когнітивний складник, що відображається в потребі покращення професійних навиків, виробленні аналітичних і рефлексивних здібностей. Третя частина - емоційний компонент, де прослідковується тісний зв'язок із психологічними та поведінковими особливостями фахівця, а саме: демонстрація емпатії, можливість об'єктивної оцінки ситуації, контроль поведінки й дій, що в сукупності позначається на моделі комунікативної взаємодії. Особистісний компонент $є$ детермінантом індивідуальних якостей і чеснот, де чинне місце посідає толерантність, здатність до співчуття, повага, уважність; афіліація та емоційна стабільність. Професійна підготовка медичного персоналу не обмежується високим рівнем фахових знань і постійно провокує виклики, пов'язані з психоемоційним напруженням, відповідальністю, дефіцитом часу та інформації, тому цілком виправданою $є$ потреба в професійній комунікативній компетентності.

Питома вага успішності опанування й засвоєння навичок реципієнтом припадає на педагогічну технологію, що домінує в рамках навчального курсу. Незалежно від формату навчання педагогічна технологія повинна відповідати таким основним методологічним вимогам (технологічним критеріям концептуальності, систематичності (у т. ч. логічності), ефективності) і відповідному рівню педагогічної технології:

1) концептуальному (теоретичному);

2) технологічному (організація навчального процесу);

3) процесуальному або практичному (конкретні дії);

4) технічному (доступні засоби навчання).

Разом із цим технологія, на відміну від методу, не передбачає мінливості, жоден елемент не може бути упущений. Постійний зворотний зв'язок, корекція та зміни в майбутній діяльності $€$ обов'язковими для практичного блоку навчання лікарів.

Як правило, в умовах офр-лайн навчання реалізація вищевказаних етапів не викликає суттєвих труднощів у жодної зі сторін навчального процесу, проте значна кількість відкритих питань залишається тоді, коли йдеться про дистанційну освіту і взаємодію студента з викладачем. Першим критичним аспектом, із яким, як правило, виникає проблема - це рівень цифрової грамотності викладачів і студентів. Решта стосується адаптації до 
взаємодії в он-лайн площині, тобто використання тих переваг, що дає такий формат роботи; оптимізація контенту навчальних матеріалів і посібників; розподіл часу в співвідношенні «лекція - практичне заняття». Із цього виходить, що специфріка дистанційного навчання майбутніх лікарів полягає в інтенсифрікації ролі самовиховання належних професійних комунікативних навичок.

Оптимізація процесу опанування кращих комунікативних навичок у потенційних лікарів в умовах дистанційної роботи не може проводитися без певних модифрікацій, яких зазнає начальний матеріал. У рамках практичного дослідження ми взяли за основу робочі зошити студентів-медиків 3 української мови за професійним спрямуванням, авторства Н. Литвиненко. та Н. Місник [5], що створювалися для роботи в офр-лайн режимі.

Організаційна частина. Так, робочий зошит по завершенню кожної комунікативної теми містить блок завдань, що передбачають написання як розгорнутих відповідей, так і тестування. Що стосується останнього, пропонуємо на період дистанційної взаємодії викладача та студента перевести їх в он-лайн фрормат з обмеженням часу. Річ у тім, що у відповідний спосіб автоматично вирішується декілька важливих освітніх завдань:

- суттєво прискорюється обробка й аналіз відповідей, автоматично підбивається загальна статистика щодо кількості коректно наданих відповідей і тих, які потребують додаткового опрацювання;

- напрацьовується рефлексія в студентів-медиків (у т. ч. за рахунок стислих дедлайнів);

- збільшується питома вага раціонально використаного часу на засвоєння теми.

Найпростішим способом цифрровізації фіксованих завдань $є$ інструменти Google, зокрема Google Forms чи Google Classroom. Окрім зазначеного, можна скористатися сервісом Surveymonkey, Polleverywhere, Wooclap (передбачає доступ на шести мовах, що не менш важливо при взаємодії 3 іноземними студентами), Kahoot. Цікаво, що саме останній ресурс відкрив безкоштовний доступ для вищих навчальних закладів на період карантинних заходів, що дало змогу оцінити його об'єктивні переваги.

Адаптація навчального контенту. У частині вивчення теми «Науковий та офіційно-діловий стиль у медичній практиці» до практичних завдань доречно долучити роботу із сучасними видами документів. Наприклад, завдання, присвячені розвитку навичок написання автобіографрії, можуть бути модифріковані чи розширені за рахунок мотиваційних листів (curriculum vitae CV) і методики їх складання. На практиці це буде корисне не лише при прийомі на роботу у вітчизняні та закордонні клініки, а й стане невід'ємною частиною в рамках міжнародного стажування, обміну практичним досвідом, реалізації трудового потенціалу в окремих галузях медицини. Як теоретичний розділ цього сегменту, так і практичні завдання доречно доповнити орієнтовними фрразами-кліше загального вжитку («Маю змогу представити себе кандидатом на посаду ... в ...», «Я впевнений у своїй здатності досягти успіху як ...», "Моя освіта служить основою для мого успіху в галузі медицини...», "При перегляді вашого оголошення про (вакансія/стажування/ обмін досвідом) .... я був приємно здивований, виявивши, що Ваші вимоги відповідають тому, що я пропоную як профресіонал», «Протягом своєї академічної кар'єри я інтенсивно вивчав...», "Окрім мого досвіду, я маю...», «Як правило, я орієнтований на пацієнта й застосовую комунікативні та лідерські навички») і тими, що більш адаптовані під спеціалізацію працівника медичної сорери (наприклад, можна взяти синтаксичні конструкції, що будуть притаманні CV мануального терапевта: «Я спеціалізуюсь на лікуванні опорно-рухового апарату, зокрема проводжу нервово-м'язово-скелетну терапію, включаючи корекцію хребта й інших суглобів пацієнта; розробляю індивідуальні плани лікування в клінічних умовах(удома...»). У процесі взаємодії викладача і студента в режимі он-лайн доречно провести мозковий штурм, спільними напрацюваннями й доповненнями створивши кращий зразок CV майбутнього лікаря.

Успішна демонстрація себе як фахового працівника неможлива без опанування медичної термінології та оперування лікарським дискурсом. Це має відбуватися на синтаксичному, фонетичному, словотвірному, фразеологічному та граматичному рівнях. Левова частка проблем виникає 3 прикладними аспектами мовознавства, а саме тими, що стосуються збільшення в студентів синонімічного ряду та вивчення етимології й семантики медичних лексем/фрразем іншомовного походження. Стосовно останнього зауважимо, що синтаксичним одиницям і конструкціям лікарських комунікацій характерно формування 3 кількох коренів. Так, в Українсько-англійському ілюстрованому медичному словнику Дорланда перераховано близько 80 слів із соматичним компонентом дерм- (грец. derma шкіра) і 129 термінів, що включають цю частину [7, т. 1, с. 505-510]. Як правило, їх класифікують на компоненти, орієнтовані на позначення процесів (дерматоавтопластика, дерматофрітид, дермоліпектомія), захворювань (дерматобіоз, дерматопатія, дерматорагія, дерматоміаз), фрахівців (дерматолог), медичних приладів або інструментів (дермогігрометр, дерматом, дермабрадер).

Не рідше зустрічаються терміни-композити 3 відповідними міжнародними компонентами: 
аур (и)-, от (о)-, фаринг (о)-, ларинг (о)-: ларинголог, фрарингіт, отосальпінкс, отобіоз тощо. Відштовхуючись від цього блоку, можна запропонувати студентам у межах частини заняття продемонструвати щонайбільшу кількість однокореневих термінів у межах медичного дискурсу. Опанування цієї тематики позитивно вплине на розширення синонімічного запасу лікарів. У процесі комунікації з пацієнтами важливо доступно пояснити суть проблематики та специфіку лікування, де в нагоді стане міжрівнева синонімія. Як правило, вона має місце у випадках, коли в синонімічне відношення вступають композит іншомовного походження та український відповідник: гепатоліт - печінковий камінь; нейрорафія - шов нерва; ішурія - затримка сечі; гемотрансфузія переливання крові; гібридне словосполучення та іншомовний композит: ангіоневроз - судинний невроз, анероїд - металевий барометр; гемограма - лейкоцитарна формула.

На збільшення словникового запасу медика та комунікативних навичок суттєво вплине проходження й заслуховування он-лайн лекцій, семінарів, участь у тематичних форумах. Викладач може залучити або порекомендувати відповідні ресурси, котрі пропонують доступні матеріали різного спрямування (наприклад, Аксемедін, ПостНаука, Prometheus, Bazyl, E Molecules тощо). Не варто залишати поза увагою такі тематичні pecypси, як MedLine, що позиціонуються як агрегатори наукових статей і досліджень із медичних наук. Особливість цього сервісу зводиться до наявності пошукової платформи PubMed, що відсортовує актуальні дані згідно із запитом користувача та дає змогу для інтерактивного зв'язку 3 автором публікації. 3 філологічної точки зору це важливо не лише для фахового зростання, а й матиме позитивний вплив на формування власного комунікативного стилю, адже суб'єкт пізнання швидко адаптується й звикає до тих категорій, якими оперують викладачі та колеги, що певною мірою гальмує вищевказаний процес.

Убачаємо за доцільне в ознайомленні студентів у рамках дистанційного навчання зі спеціалізованими платформами, присвяченими розвитку саме мовно-комунікативних здібностей як у студентів-медиків, так і в лікарів-практиків. По праву найліпшим ресурсом уважається WONKA (https://www.globalfamilydoctor.com/), створений Усесвітньою організацією сімейних лікарів і покликаний заохочувати високі стандарти медичного супроводу.

Суттєве збільшення кількості практичних та інтерактивних завдань можливе для блоку комунікативних тем, зокрема «запис скарг хворого й історія захворювань», «історія життя хворого», «дійсний стан хворого та попередній діагноз». Перші візити до лікарня, налагодження інтуїтивно-довірливого контакту, можливість почути та зрозуміти пацієнта значно впливають на подальший процес і динаміку лікування. На цьому етапі важливо роз'яснити студентам цінність морально-етичних засад у лікарській практиці й дотримання принципу конфіденційності інформації про стан здоров'я кожного пацієнта.

3 метою оцінки ступеня сприйняття матеріалу варто застосовувати систему ситуативних кейсів чи практикувати роботу в парах. Варіативно-ситуативний рівень взаємодії позитивно віддзеркалюється на діалогічному та монологічному мовленні. Зокрема, можна запропоновати такі теми тренінгу: 1. Невербальна комунікація (як зрозуміти, відчути іншу людину?). 2. Невербальна комунікація (як правильно почути іншу людину?). 3. Установлення контакту й дистанції в спілкуванні з пацієнтом-дитиною (рольова гра). 4. Висловлюємо почуття - розуміємо себе (арт-методи).

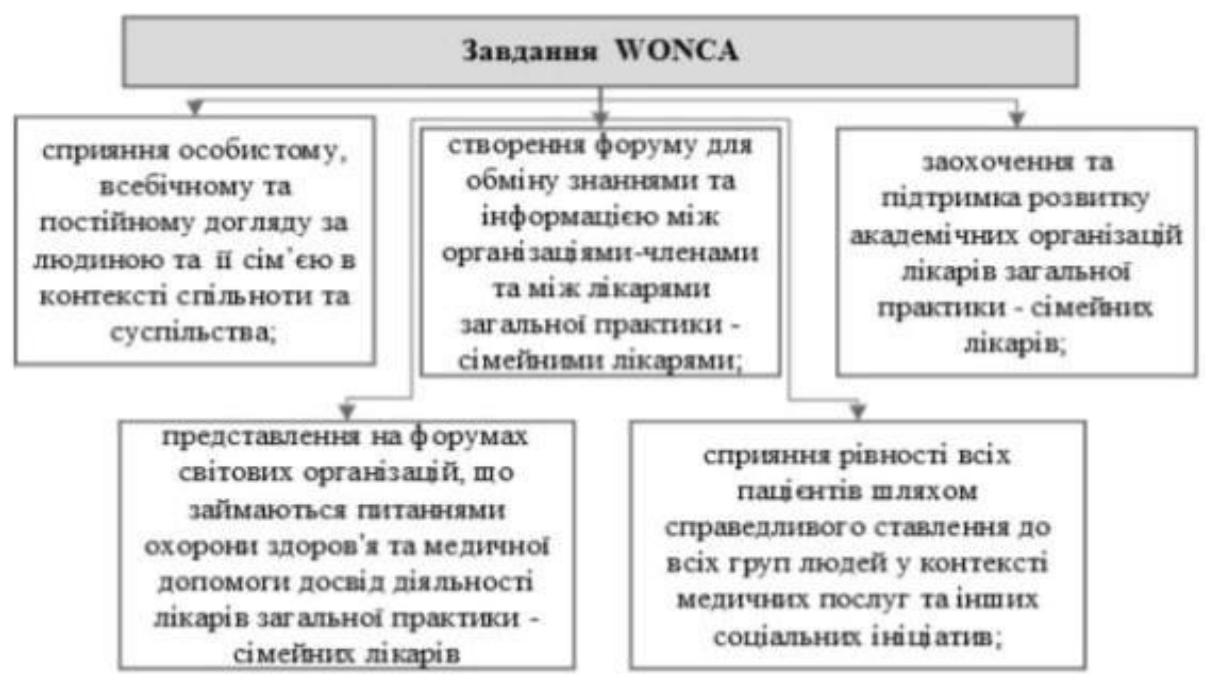

Рис. 1. Завдання WONKA 
Нерідко трапляються випадки зовнішніх (лікар - пацієнт; колеги-лікарі) та внутрішньоособистісних конфліктів (як наслідок - призводить до фррустрації) у роботі лікаря. 3 метою запобігання таким негативним ситуаціям і врегулювання їх доречно відпрацювати з студентами відповідні методики. Оптимальними техніками для ознайомлення студентів є медіація, фасилітація, переговори, психологічні консультації тощо. Наприклад, у грі беруть участь студент 1 (пацієнт), студент 2 (лікар) і викладач (у ролі медіатора/посередника). У процесі обговорення (наприклад, ситуація: пацієнт $€$ прихильником однієї методики лікування зубів, проте стоматолог пропонує альтернативний варіант, що викликає сумніви в пацієнта) студент 2 має переконати 3 дотриманням морально-етичних принципів, на яких базується його діяльність, у власній компетентності й корисності його поради пацієнта. Коли одна зі сторін модифікує тон, нервує, проявляє підвищений рівень збудження, унаслідок чого ситуація заходить у «глухий кут», у гру вступає нейтрально налаштована третя сторона (викладач), яка спрямовує суб'єкти на пошук альтернативного рішення. По звершенню гри змінити ролі між учасниками попередньої, зробити усний детальний аналіз (мозковий штурм) щодо помилок, яких припускаються учасники імпровізованої ситуації, або написати есе на цю тематику.

Висновки і пропозиції. Отже, у результаті опрацьованої тематики нами встановлено, що дистанційна взаємодія викладача і студентів нині позиціонується не як вимушений чи ускладнений етап освітнього процесу, а радше як нова можливість для різностороннього розвитку майбутніх лікарів і розвитку комунікативних навичок із застосуванням інформаційно-комунікаційних технологій. У зазначених умовах важливо коректно організувати он-лайн формат взаємодії й оптимізувати навчальний матеріал і його контент відповідно до тих можливостей, які надають інформаційно-комунікаційні платформи. Цілком виправдано з боку викладача акцентувати увагу саме на комунікативній тематиці та розвивати в студентів діалогічне й монологічне мовлення, оперуючи професійною лексикою. Подальші наукові пошуки на базі окресленої тематики вбачаємо в експериментальних перевірках ефективності впливу дистанційного навчання на розвиток комунікативних навичок.

\section{Список використаної літератури:}

1. Бацилєва О.В., Астахов В.М., Пузь І.В. Роль комунікативної компетентності у професійній діяльності лікарів. Медична симуляція - погляд у майбутнє (впровадження інноваційних технологій у Вищу медичну освіту України) (для лікарів, науковців та молодих вчених) : тези доп. наук.-практ. конференції з міжнародною участю (Вінниця 08.02.2019). Вінниця : ВНМУ імені І.М. Пирогова, 2019. C. 5-6.

2. Варданян А.О. Формування професійно-мовленнєвої компетентності майбутніх лікарів : дис. ... канд. пед. наук : 13.00.04. Хмельницький, 2017. 285 c.

3. Формування професійної компетентності майбутнього лікаря на прикладі студентів медичного факультету ТДМУ. Вдосконалення вищої медичної освіти / І.О. Крицький, П.В. Гощинський, Т.І. Крицький та ін. ; Тернопільський державний медичний університет імені І.Я. Горбачевського MO3 України. Медична освіта. 2018. № 3. C. 44-48.

4. Кузьмина Н.В. Профрессионализм личности преподавателя и мастера производственного обучения / ВНИИ проф. техн. образования. Москва : Высш. школа, 1990. 117 с.

5. Литвиненко Н.П., Місник Н.В. Українська мова (за професійним спрямуванням): робочий зошит студента-медика : навчальний посібник : у 2 ч. Київ : Фенікс, 2020. 80 с.

6. Тітова А.В. Формування профресійної компетентності майбутніх сімейних лікарів із використанням веб-технологій : дис. ... докт. фрілософії : 015 «Професійна освіта» / Полтавський національний педагогічний університет імені В.Г. Короленка. Полтава, 2020. 358 с.

7. Українсько-англійський ілюстрований медичний словник Дорланда (переклад 30-го, амер. вид.) : у 2 т. Львів : НАУТІЛУС, 2007. Т. 1. 1248 с. ; T. 2.1024 c.

8. Українська термінологія і сучасність : збірник наук. праць / відп. ред. Л.О. Симоненко. Вип. VІ. Київ : КНЕУ, 2005. 448 с.

Nikolaiev V. Formation of professional language and communication competencies of future doctors in distance learning

The article focuses on the study of forming language and communicative competencies in the framework of online interaction. The relevance of the research is determined by the challenges in modern society, which demand from educational institutions and students, medical workers in particular, mastering and using information and communication technologies to increase the level of professional competence,

The aim of the research is a theoretical analysis of the directions to optimize educational content and remote interaction from the organizational point of view in the framework of improving the communication skills of future professionals. The main methods are induction, modeling, synthesis, analysis, extrapolation.

The paper proves the positive impact and outlines the significant advantages of distance learning as one of the formats to develop language and communication competencies of future doctors. The concept of "professional competence" is studied, the attention is focused on its integrative nature. The role of the dominant 
pedagogical technology within the relevant training course is highlighted. The intensification of the role of selfeducation to get appropriate professional communication skills as a specific feature of distance education is pointed out. The constituent elements of the communicative competence of the future doctor are revealed.

The organizational possibilities provided by distance learning at the current stage of development of science and technology are demonstrated, moreover certain ways to adapt the content and communicative interaction are offered. Emphasis is placed on the need for interactive games, the development of professional language and communication skills through situational cases, which have to develop medical students' dialogic and monologic speech. In these conditions, it is important to correctly organize the online format of interaction and optimize the training material and its content in accordance with the opportunities provided by information and communication platforms. The teacher is supposed to focus on communicative topics and to develop students' dialogic and monologic speech, using professional vocabulary. The authors see further scientific research on the basis of the outlined theme in experimental tests on the effectiveness of the impact of distance learning on the development of communication skills.

Key words: distance learning, communicative competences, a future doctor, "professional competence". 